\title{
Temperament-Conscious Humanistic Pedagogy
}

\author{
Mare Leino $^{1^{*}}$, Sari Mullola ${ }^{2}$ \\ ${ }^{1}$ Social Work Institute, Tallinn University, Tallinn, Estonia \\ ${ }^{2}$ IBS, Unit of Personality, Work and Health Psychology, University of Helsinki, Helsinki, Finland \\ Email: " mareleino@hotmail.com, sari.mullola@helsinki.fi
}

Received 25 March 2013; revised 18 April 2014; accepted 9 May 2014

Copyright (C) 2014 by authors and Scientific Research Publishing Inc.

This work is licensed under the Creative Commons Attribution International License (CC BY).

http://creativecommons.org/licenses/by/4.0/

\section{(c) (i) Open Access}

\begin{abstract}
Education is a human right, but some youngsters still drop out of school. One reason for that might be student's teacher-perceived inappropriate or even "wrong" temperament (i.e., individual's innate way to approach and react to the environment) for school environment. There is a lot of evidence that the school grades are mostly based on teacher-perceived ratings rather than standardized tests. Temperament can be seen as a non-academic aspect of educational process, but it strongly influences academic outcomes. Final marks will direct (through universities or lack of education) one's place in the labour market, and people's general well-being with the subjective perceptions of happiness and self-esteem. The aim of this research has been to develop the field: temperament can't be the reason of (good or bad) grades. Humanistic teachers of 21st century should have better knowledge's in psychology, especially in the context of temperament. To integrate temperament-conscious pedagogy (i.e., the acceptance of temperamental background of the behaviour as a part of teachers' didactical, pedagogical and practical knowledge) in regular teacher training it might be possible to identify potential difficulties in educational pathways and prevent social exclusion. The aim of this article is to analyze conceptual similarities between humanistic education, social pedagogy and temperament-conscious teaching-to show their significant joint part. The research method used here is the content analysis of definitions.
\end{abstract}

\section{Keywords}

Temperament, Humanistic Education, Temperament-Conscious Education, School Grades, Humanistic Pedagogy

\section{Introduction}

Education is a human right, but in the year 2010 the Statistical Office of Estonia published figures which

${ }^{*}$ Corresponding author. 
showed that, within the 15 - 24 age group, 12.4\% were out of education and/or labor market position (Statistical Office of Estonia, 2014). This is not only "kind of Baltic problem": according to statistics, published by the Department for Education of England, almost one in five 16- to 24-year-olds in England were "NEET" (i.e., not involved in education, employment and/or training) between July and September 2011, a figure which has risen by 137,000 compared with the same period in 2010 . The figures also show that just over $21 \%$ of 18 - to $24-$ year-olds are not in education, work or training (Allen, 2011).

One can find similar statistics around the world-especially in context of financial crisis, which has led to a challenging situation in global labor markets. The reasons for this include financial problems in the family, inadequate teaching methods at school, special needs or/and multicultural background of students (Kallavus \& Tiko, 2006: p. 78; Leino \& Männiste, 1996; Leino, 2002a, 2010, 2011, 2013). Among “inadequate” teaching methods, subjectivity of teachers can be an extra factor, which may be also gender-related. In a series of Finnish studies among upper-comprehensive school students $(\mathrm{n}=3212)$ (Mullola et al., 2012; Mullola et al., 2011; Mullola, Ravaja, et al., 2012; Mullola et al., 2010) teachers perceived the temperament (i.e., and individual's unique, innate way of approaching and reacting to the environment) and teachability (i.e., teacher's perception of the attributes of an ideal model student defined by Keogh) (Keogh, 1994) of boys to be less appropriate to the school context than that of girls' (Mullola, 2012: p. 59).

Temperament can be seen as a non-academic aspect of educational process, but it strongly influences academic outcomes. Final marks will direct (through universities or lack of education) one's place in the labour market, people's self-esteem, etc. There is a great body of evidence that the school grades are mostly based on teacher-perceived ratings rather than standardized tests (Jussim \& Harber, 2005; Keogh, 2003; Martin, 1989), and likely to be influenced by subjective perceptions of the teachers that reflect teachers' personal expectations, opinions, values, and attitudes. Psychologists (Burks \& Rubenstein, 1979: p. 42; Keltikangas-Järvinen, 2009) emphasize the communication of temperament style as the basis of harmonious interpersonal relations, because it forms the base for a healthy self-image and for individual autonomy. In a recent population-based Finnish study of 9th graders, the temperament factors of activity, persistence, distractibility, inhibition and negative emotionality were significantly associated with both Mother Language and Math grades, explaining together 28\% and 29\% of the variance (Mullola et al, 2010: pp. 211-212). This kind of subjectivity (or personal conflicts/ misunderstandings between students and teachers) is not the sign of humanistic approach, and might be considered as one of the reasons for school conflicts and dropout.

The aim of this research has been to develop the field: temperament can't be the reason of (good or bad) grades. Humanistic teachers of 21st Century should have better knowledge's in psychology, especially in context of temperament. The idea of this article is to analyze conceptual similarities between humanistic education, social pedagogy and temperament-conscious teaching - to show their significant joint part.

The research method used here is the content analysis of definitions.

\section{Humanistic and/or Temperament-Conscious (Social) Pedagogy}

In Latin the word "socialis" has the meaning of being friendly as well as social. Saying that one is friendly holds a social relation in itself: one is friendly towards/to somebody (like in social pedagogy, humanistic, and/or in temperament conscious teaching). One of the solutions to school problems (or a way of preventing the NEETproblem) could be the mix of social and academic pedagogy. If some extra-curricular aspects (like temperament, students' personal working style, etc.) would be tolerated in class (to a certain extent), the dropout rate (and NEET-problem) could probably decrease (Leino, 2011, 2013). This is the reason, why humanistic education is so important for whole society.

Historically the school has had several functions in addition to sharing knowledge. After child labour was forbidden in many countries in the 19th century, parents had to work harder to compensate for the income they lost because their children had stopped working. They were working longer hours, and the children were unsupervised. Establishing a network of schools helped to solve the unwanted by-product of the industrial revolution: the possible criminal activity of the underage tramping youth. So the effect of school education in those times was manifoldly humanistic: the new educated generation with academic knowledge also proved to be better factory workers than the one without education.

When the power of the church decreased in the 19/20th century, the school had to overtake the task of socializing the new generation. In some languages (for example in Estonian) the same word (teacher) is in use for the 
schoolteacher and for the vicar. This is a sign of high humanistic expectations of the society for both professions - especially in the context of discipline, guarding and socialization (Leino, 2011). Veugelers (Veugelers, 2011a) sees education as a moral enterprise that shapes human development. Moral values are at stake at the level of educational systems, of schools and of individual teachers. From a humanistic point of view social change is not possible without strong and critical autonomous people. For education this means that learning is not a technicalinstrumental rationality but identity development in a reflective and dialogical way in a social context; it is morally social constructivism (Veugelers, 2011a: p. 1).

In many countries besides of the word "pedagogy" there is also "social pedagogy" in use. The theoretical reason of different concepts is the speciality of contents, but in reality the aim of those words is quite similar: effective education is always kind of social; and the humanistic socialisation is (mostly) educational. According to Pinker the power of a definition is that it transcends the particulars of experience (Pinker, 1999: p. 302). According to Hämäläinen (2012), pedagogical activities for preventing social exclusion and promoting active citizenship are closely linked (Hämäläinen, 2012: p. 13). This is the point where academic pedagogy meets humanistic social pedagogy. Preventive tolerance in context of temperament-conscious education (i.e., the acceptance of temperamental background of the behaviour as a part of teachers' didactical, pedagogical and practical knowledge in regular teacher training as well as in daily school teaching) gives as result an active socialization. As the prosocial teaching avoids bigger problems, emotions should never be underestimated. Lewin (as cited in Forgas, 1981: pp. 10-11) wrote many decades ago already, that the perceived, cognitively interpreted situation is the one which is related to behaviour, and not the external, objectively manipulated situation (Forgas, 1981: pp. 10-11). According to Damasio (2006) feelings (along with the emotions they come from) serve as internal guides, and help us to communicate to others signals that can also guide them. Feelings are neither intangible nor elusive. Contrary to traditional scientific opinion, feelings are just as cognitive as other percepts. They are the results of a most curious physiological arrangement that has turned the brain into the body's captive audience (Damasio, 2006: p. xxv).

The knowledge about the cognitivity of feelings should be part of temperament-conscious pedagogy: the emotional effect of humanistic education is at least as important as academical. If feelings are cognitive, academic marks have emotional output- “ordinary” pedagogy has social influence through psychology (through student's self-esteem).

Moreover, if about 1/3 of the content of marks depends on teachers' subjective impression, the situation may not be seen as humanistic. Recent research has indicated that pleasant students get good marks more easily, compared to children with a "bad" temperament (i.e., inappropriate and/or unwanted temperament in school context) (Mullola, 2012). This is like a power game: a teacher decides who needs rehabilitation, who not. Teaching subordination is one of the activities at school. Whatever the teacher does (or does not do) has a social influence, even if it seems academic. To minimize the subjectivity in the context of marks, humanistic teacher should be kind of social pedagogues (with knowledge's of temperament-conscious teaching).

\subsection{The Meaning of Humanistic Education}

According to Veugelers (2011a: p. 2), the present-day humanism strongly focuses on personal development in relation to others. He stresses that humanism is about personal autonomy, moral responsibility, and about solidarity with humanity. Humanism is about personal autonomy, moral responsibility, and about solidarity with humanity. Human solidarity restricts autonomy and connects the individual and his environment. It is always about the dynamics between autonomy and social involvement. These dynamics can still have a large diversity of theoretical and practical interpretations. The diversity should be judged as positive, because it will contribute to a lively communication about moral values and will prevent that the values of one group are all too easily established as the norm for everyone. Diversity challenges everybody to reflect on one's personal values (Veugelers, 2011a: p. 2).

In developed countries going to school is obligatory: education as fulfilling the law is the only way to get a proper standard of humanistic life. Thereby, the teacher represents the state- $\mathrm{s} / \mathrm{he}$ enables, guarantees and controls the schooling and learning. By giving homework, for example, a teacher can control children's time even after the school day has finished. The process of teaching has an academic content, a humanistic aim, but a social form: the young person has to go through all classes, pass exams-only then it is possible to enter life (Leino, 2011). So-in some contexts academic, humanistic, psychological and social are partly synonyms. 
Veugelers (2011b: pp. 18-24) stressed the quality of education, which should be assessed not only in terms of individual "academic" school performance of students, but also on the contribution education makes to social justice and motivation for social change. Teaching is seen as social and moral engagement to create a better and more just world (Veugelers, 2011b: pp. 18-24). Hence, moral, social and humanistic really seem to be kind of synonyms.

The new field of relationships, under the meaning of "social", was widely recognized by the end of the 19th century - it denoted a specific field outside of politics, that was also connected to a pedagogical aspect: people started to connect social problems (including poverty) with school (to be more exact-with the lack of education) (Leino, 2011). In some areas (Baltic countries, Scandinavia, Germany) the use of the word "social" is narrower than "societal"-for example if one talks about people in need, and how to support them. In this case the word "social" has an opposite meaning to the word "economic" (Leino, 2011). For Durkheim the word "social" was equal to norms, which were thought to be the putty of whole society (Durkheim, 1895). A "social" person fits to standards, unlike the "asocial" one. It is normal to cope by yourself, not to burden the taxpayers. No wonder then that during significant societal changes, in the draught of the industrial revolution, the scientific fields of socio-prefix started to become a reality: sociology (to investigate the problems), social psychology (to understand their essence), social work and social pedagogy (to solve them). "Social" as being able to cope (for example through education), or as the introduction of norms, or as the promotion of co-operation are important both for the school and the teacher. According to this, the educational activities support the process of humanistic socialization. In ideal world the whole education should be called social pedagogy or temperament-conscious teaching - it avoids drop-out and other psychological problems. Furthermore, in ideal, humanistic world the students' marks are result of knowing, not of ("proper") temperament.

\subsection{The Meaning of (Social) Pedagogy}

Students' expectations of the school are different, and not all of them adapt to the culture of the school that stresses mostly middle class values (Silvennoinen, 1992: p. 259). The middle class values of Estonia mean having or striving for a good work place and coping with one's own life-also the teacher gives importance to this. "Bad pupils" are threatened with not getting into secondary school, which in Estonia means the status of an outcast (Leino, Hintsanen, Hintsa, Merjonen, \& Keltikangas-Järvinen, 2013). A concrete example of this is that evening schools in Estonia are situated only in bigger cities. As the unsuccessful will turn out to be a burden to the tax-payer, these poor people are scolded from their early year son wards. Problems in studies predicts further difficulties in the labour market and as the social security system in Estonia is poor, teachers as well as parents take deviations from the norm as a tragedy. From the point of view of school the "proper citizen" in Estonia seems to mean a Soviet-type obedient factory worker. Giving out information mostly in one direction-from teacher to student—excludes dialogue and individual reflection. The "previous" education rested on similarities. Contemporary society, however, needs independent and creative people for faster development. There is probably a tension between emancipation and regulation in the schools of Nordic countries as well (Gordon, Holland, \& Lahelma, 2000; Leino \& Lahelma, 2002: p. 84), but in post-Soviet countries the conflict between society and the conservative school is more acute because of the intensive changes in society during a very short time (Leino, 2011). Too often troubled behaviour is considered as a permanent characteristic of the person, even as an illness that has to be diagnosed (Nygard, 1998: pp. 23-24). This can be seen particularly in post-Soviet countries, where people have been taught for 50 last years that the only norm is average behaviour, appearance etc. (Leino, 2002a).

According to definition of National Board for Professional Teaching Standards (Washington, 1998) the content of the pedagogy refers to the pedagogical (teaching) skills teachers use to impart the specialized knowledge/ content of their subject area(s). Effective humanistic teachers display a wide range of skills and abilities to create a learning environment where all students feel comfortable and are sure that they can succeed both academically and personally. This complex combination of skills and abilities is integrated in the professional teaching standards that also include essential knowledge, dispositions, and commitments that allow educators to practice at a high level (Washington, 1998). In this definition the "comfortable feeling" and "personal success" are important concepts, because emotional well-being helps humanistic socialization. As Damasio put it: "feelings are just as cognitive as other percepts” (Damasio, 2006: p. xxv).

Emotions, feelings and sociality are part of both "ordinary" and social pedagogy-they influence academical results and support the everyday life at school. Some of NEET-youngsters are probable out of school because of 
“wrong temperament”.

There is increasing evidence that student's temperament plays a significant role in teachers' conceptions (Mullola et al., 2011), affecting their student-teacher relationship (DiLalla, Marcus, \& Wright-Phillips, 2004; Rudasill \& Rimm-Kaufman, 2009), their attitudes toward the student (Guerin, Gottfried, Oliver, \& Thomas, 1994, 2003), their expectations concerning his or her abilities (Keogh, 1994; Martin, 1989; Mullola et al., 2010), and even their teaching decisions (Keogh, 1989; Rothbart \& Jones, 1998). If teachers' subjective impressions influence marks so strongly, the pedagogy is instead of social rather anti-social. Every activity to keep students in the educational system is important, because the prevention of dropout avoids societal problems. In this context the temperament-conscious teaching can be considered as a humanistic social pedagogy.

According to Hämäläinen (Hämäläinen, 2012: p. 12), the social pedagogy does not have methods of its own that could be distinguished from pedagogical methods in general. Nyqvist (Nyqvist, 1997: p. 31), in turn, stresses empowerment, which in this context means the process of improvement-how to make the situation more comfortable for people. Like a good teacher, the social pedagogue gives an impulse for development. The question is: how to support the humanistic development of everybody? The task of social pedagogue is considered to be that of developing social and upbringing theories as well as vocational work and training (Hämäläinen \& Kurki, 1997: p. 15).

According to Nyqvist (1997: p. 32) for young people the social pedagogy means "possibilities to increase the social competence: how to avoid bad influences from social and psychological environment. Or, to be more exact-how to support the creativeness and activity of youngsters” (Nyqvist, 1997: p. 32). At school one will know how to act. According to Hämäläinen, the social pedagogy can be called an action science, because it is closely connected with the challenges of pedagogical action, either professional or non-professional, in theory and practice (Hämäläinen, 2012: p. 11). In academic pedagogy the action is important also-for example in context of temperament. An attempt to separate the concepts of social, humanistic, temperament-conscious and “ordinary” pedagogy is probably not fruitful, because they all are tools of socialization.

The social approach involves workers identifying and being clear about the values they wish to promote and purpose fully encouraging those value sthrough the use of praise and other rewards (Forgas, 1981: p. 19). It also involves appropriate modelling of the values the worker seeks to promote, and challenging anti-socialorprocriminal expressions and actions (Forgas, 1981: p. 19). Children and adolescents need supervision in their everyday life. As Keltikangas-Järvinen (2011) puts it, "it is important to comment and to direct them as soon as possible”. Effective pedagogical acting is always both prosocial and social.

In a recent study of Finnish comprehensive schools, students with low temperamental task orientation (i.e., activity, distractibility, and persistence), low educational competence (i.e., cognitive ability, motivation and maturity), low personal-social flexibility (i.e., approach, positive mood, and adaptability), and high reactivity (i.e., negative mood, intensity of response, and reactivity) were perceived as less capable and less teachable by their teachers and received lower school grades (Mullola, 2012). These results are not surprising in Finnish culture where restrained behaviour is a common and important aspect in all individuals' activities. Thus the spontaneous expression of feelings, especially negative ones, is somewhat inadvisable in the Finnish cultural and educational climate (Mullola, 2012: p. 63). This might explain, at least partly, the problem of "problem” children and NEET-youngsters as well.

The role of educational order is to support the passing of the curriculum and the functioning of the hidden curriculum. The last one consists of unwritten rules, norms and order, which, if ignored, will result a punishment. Children with different social backgrounds are therefore in unequal situations. For example, not all families use the correct official state-language-some confine themselves to slang, cursing and grammatically wrong language. In situations like this the teacher has at first to teach the pupils to talk, and only after that the teaching of the subject will be possible. Here the social, humanistic aspect of teaching is obvious.

There are many children in school class, and most of the time the teacher has to work with a group. S/he even talks in we-form: “Let's take our textbooks out!”, “Let's solve this exercise!”. This form of speaking refers to a collective, but also to impersonality. The child gets used to the fact that at school s/he changes from a rare subject to an element of a larger mass-just into a line of the list of pupils in the class. Sometimes several days may pass before the teacher approaches a pupil by their name. It also happens that some pupils start to behave badly on purpose- just to get personal attention from the teacher. Obviously political decisions in the Estonian education field (big classes, the lack of an assistant teacher etc.) can cause a new problem (badly behaving children), which requires an extra social role of the teacher, who has to socialize all students—both with "right" or "wrong” 
temperament. In Finland the state supports teachers and schools more than in Estonia, but even in Finland the subjectivity of teachers seem to be a problem (at least in context of temperament) (Mullola, 2012).

This process is deeply connected with cultural norms. Caspi and colleagues (Caspi, 1998; Caspi \& Shiner, 2006) have presented the concept of "cumulative continuity", where temperament-related consequences may be combined and elaborated over the course of time. The statistics about NEET-youngsters is probable a result of this cumulative process. If the temperament factors of activity, persistence, distractibility, inhibition and negative emotionality have been found to explain about 1/3 of marks (Mullola et al., 2010: pp. 211-212), there is a paradox: the aim of pedagogy is humanistic; but activities are sometimes repressive (if one's temperament is "too visible", for example). Officially all people are equal, but in reality some students get worse marks just because of working style or “unproper” emotions. Teachers usually don't feel sorry about this, because one of the school's duties is to socialize "reasonable" citizens. As a result some students will drop out, and social problems in society increase.

So-if the socialization is too intensive, in some cases instead of effect one can recognize rather a defect. The solution could be a humanistic social pedagogy. If the social pedagogy is rather a way of thinking (in which social and educational considerations are united) (Hämäläinen, 2012), and when in teachers' education the social pedagogy could get a significant role, the temperament probable would not influence students' marks so much anymore. Shortly: prosocial education avoids social problems. Bierhoff understands (pro) social behaviour as part of social competence (Bierhoff, 2002: p. 53)—which is important for both teachers and students.

\section{Discussion}

Teacher, who wants to support the humanistic socialization, stresses not only the academic content of the curriculum, but social relations in school, too. At least it should be so. This is on the shoulders of a teacher to make studies more humane. The teacher is forced to balance the bureaucratic coldness of school and suggest safety to students (Aittola, 1999: p. 204). From this perspective a paradox arises: school routines do not support behaviour that is suitable for children (joy and play) — this kind of opening oneself is considered to be punishable behaviour. At the same time in the work descriptions of social (and special) pedagogue (working with so called problematic children) play, positive emotion and joy dominate (Leino, 2002a). Paradoxically the shortcomings and problems caused by the ordinary school have to be remedied by the opposite therapy that is practised in social pedagogy. The role of temperament differs in different contexts. School is a contradictory place. On the one hand teachers have to condemn unsuitable behaviour and admonish the so-called decency, but social pedagogues spend their energy to (re)form their personal relation with the children. With this kind of "off-duty" relation social pedagogues are trying to erase the stereotypes of an authoritarian teacher. As an art, humanistic socialization requires improvisation and spontaneity (Leino, 2002a, 2002b). The ideal social pedagogue is more like friend than staff of school. The ideal humanistic education should be able to accept temperament-differences of students.

\section{Conclusion}

However, let's return to the beginning of this article - to the possibility of avoiding school- and NEET-problems through temperament-conscious teaching. In next view sentences one can change the concept "temperamentconscious education" easily to the "humanistic education" and/or to the "social pedagogy"—and the message will be the same (Mullola, 2012: pp. 79-80):

"Temperament-conscious education encourages educators to understand and respect students' individual temperamental differences (e.g. in working styles) and to take this into account in their teaching-learning processes. This means that respecting different temperaments equally means equitable treatment for all students. However, temperament-conscious education should not be used to segregate students or for tailored classes and special teaching groups, but rather to create an educational climate with flexible learning circumstances and educational methods that fit all types of temperaments and not only for those who happen to have a so-called affirmative 'school temperament' with high task orientation. '/...' Temperament-knowledge might produce the most useful results when used as a supportive and comprehensive practical tool throughout the entire teaching, studying, and learning process, and particularly teachers and students working together. Temperament-conscious teachers can help students to know their strengths better and provide tools to cope with their weaknesses" (Mullola, 2012: pp. 79-80). 
If the aim of education is to understand and respect students' individual differences, both social and temperamental aspects are important. The respect and understanding are part of social pedagogy. According to Hämäläinen, social pedagogy (as a particular field of social action) is linked to the action theory that requires understanding of both aims (values) and reality (conditions) (Hämäläinen, 2012: p. 11). The general content of humanistic (social) pedagogical thought and temperament-conscious teaching is the same. The (social and/or temperament-conscious and/or "ordinary") pedagogue should meet every child as a subject, rather as an object, which can be seen as an indicator of humanistic success. Teachers (and students and parents) need to be better educated in context of temperament: "wrong" behaviour is not automatically the signal of abnormality—sometimes people just are different. Sad, if from temperamental misunderstandings, for example, the processes of being a NEET-person starts.

The founder of social pedagogy in Estonia, Johannes Käis (1885-1950), and the Emeritus Professor of Tallinn Pedagogical University, Inge Unt, have repeatedly stressed the significance of individual relationship with every child in general education. They underline that this should not be used only in a rehabilitative sense, but that individualization should be encouraged continuously, already from the beginning (Käis, 1996; Unt, 1996). According to the Estonian academician Heino Liimets (1998), the school should fill a role of an integrator in relation to all the other study processes that take place in the student's life.

The information about importance of temperament-conscious teaching is quite a new both for Finland and for Estonia, and probable for many other countries as well. The idea of this article is to stress the importance and meaning of humanistic teaching: a big problem (like NEET-status) may start from small subjective mistake (from conflict with teacher, based, for example, only on temperament). Social pedagogy and temperamentconscious teaching support in practice the same aim—-humanistic approach of education.

\section{Acknowledgements}

This study was funded by personal funding for Sari Mullola from the KONE Foundation.

\section{References}

Aittola, T. (1999). “Thomas Ziehe. Epätavanomaisen Oppimisen Puolustus” (Thomas Ziehe. The Defence of Non-Traditional Learning). In T. Aittola (Ed.), Kasvatussosiologianteoreetikoita (pp. 201-227). Helsinki: Gaudeamus.

Allen, K. (2011). Youth Unemployment Hits 1 Million. The Guardian. (published: 16.11.2011, accessed 02.04.2013)

Bierhoff, H.-W. (2002). Prosocial Behaviour. New York: Psychology Press.

Burks, J., \& Rubenstein, M. (1979). Temperament Styles in Adult Interaction: Applications in Psychotherapy. New York: Brunner \& Mazel Publishers.

Caspi, A. (1998). Personality Development across the Life Course. In W. Damon, \& N. Eisenberg (Eds.), Handbook of Child Psychology: Social, Emotional and Personality Development (5 ed., Vol. 3, pp. 311-388). New York: John Wiley \& Sons.

Caspi, A., \& Shiner, R. L. (2006). Personality Development. In W. Damon \& R. M. Lerner (Eds.), Handbook of Child Psychology: Social, Emotional and Personal Development (6 ed., Vol. 3, pp. 300-365). Hoboken, NJ: John Wiley \& Sons.

Damasio, A. (2006). Descartes’ Error. London: Vintage Books.

DiLalla, L. F., Marcus, J. L., \& Wright-Phillips, M. V. (2004). Longitudinal Effects of Preschool Behavioral Styles on Early Adolescent School Performance. Journal of School Psychology, 42, 385-401. http://dx.doi.org/10.1016/j.jsp.2004.05.002

Durkheim, E. (1895) Introduction to Sociology: The Rules of Sociological Method. http://www.cf.ac.uk/socsi

Forgas, J. P. (1981). What Is Social about Social Cognition? In J. P. Forgas (Ed.), Social Cognition (pp. 1-26). London, New York, Toronto: Academic Press.

Gordon, T., Holland, J., \& Lahelma, E. (2000). Making Spaces. Citizenship and Difference in Schools. London: Macmillan Press Ltd. http://dx.doi.org/10.1057/9780230287976

Guerin, D. W., Gottfried, A. W., Oliver, P. H., \& Thomas, C. W. (1994). Temperament and School Functioning During Early Adolescence. The Journal of Early Adolescence, 14, 200-225. http://dx.doi.org/10.1177/027243169401400206

Guerin, D. W., Gottfried, A. W., Oliver, P. H., \& Thomas, C. W. (2003). Temperament: Infancy through Adolescence. The Fullerton Longitudinal Study. New York: Kluwer Academic/Plenum Publishers. http://dx.doi.org/10.1007/978-1-4615-0175-6

Hämäläinen, J. (2012). Social Pedagogical Eyes in the Midst of Diverse Understandings, Conceptualisations and Activities. International Journal of Social Pedagogy, 1, 3-16. 
Hämäläinen, J., \& Kurki, L. (1997). Sosiaalipedagogiikka. Porvoo: WSOY.

Jussim, L., \& Harber, K. D. (2005). Teacher Expectations and Self-fulfilling Prophecies: Knowns and Unknowns, Resolved and Unresolved Controversies. Personality and Social Psychology Review, 9, 131-155. http://dx.doi.org/10.1207/s15327957pspr0902_3

Kallavus, T., \& Tiko, A. (2006). Oppivelvollisuuden Toteutuminen Virossa Koulutuksen Erityistarpeiden Lähtökohdista. (Study Obligatory in Estonia, from Special Educational Point of View). In H. Lehtonen (Ed.), Oppijan Kasvun Tukeminen. (To Support the Grouth of Student) (pp. 73-91). Saarijärvi: Saarijärven Offset OY.

Keltikangas-Järvinen, L. (2009). Temperament ja Kooliedu (Temperament and School Success). Tallinn: Lastekaitseliit.

Keltikangas-Järvinen, L. (2011). Sotsiaalsus ja Sotsiaalsed Oskused (Sociability and Social Skills). Tallinn: Koolibri.

Keogh, B. K. (1989). Applying Temperament Research to School. In G. A. Kohnstamm, J. E. Bates, \& M. K. Rothbart (Eds.), Temperament in Childhood (pp. 437-450). Chichester: John Wiley \& Sons, Ltd.

Keogh, B. K. (1994). Temperament and Teachers' Views of Teachability. In W. B. Carey, \& S. C. McDevitt (Eds.), Prevention and Early Intervention: Individual Differences as Risk Factors for the Mental Health of Children (pp. 246-254). New York: Brunner/Mazel.

Keogh, B. K. (2003). Temperament in the Classroom: Understanding Individual Differences. Baltimore, MD: Paul H Brookes Publishing.

Käis, J. (1996). Kooli-Raamat (The Book of the School).Tartu: Ilmamaa.

Leino, M. (2002a). Before and Now in the Estonian School. Young, 10, 44-59. http://dx.doi.org/10.1177/110330880201000203

Leino, M. (2002b). Country Notes: Estonia. Social Pedagogy in the Context of Social Work. European Journal of Social Work, 5, 319-321. http://dx.doi.org/10.1080/714053163

Leino, M. (2010). Kooliprobleemide Taustategurid (The Background Information of School Problems). In V. Parts (Ed.), Noored Eestis 2009 (Youngsters in Estonia 2009) (pp. 126-131). Tallinn: ENK.

Leino, M. (2011). The Child Friendly School: An Idea versus Reality. Problems of Education in the 21th Century, 29, 89101.

Leino, M. (2012). Social Role of the Teacher. In K. Lyons (Ed.), Sage Handbook of International Social Work (pp. 212-214). London: Sage Publications Ltd.

Leino, M. (2013). The (Pro)Social Context of Pedagogy. Sosiaalipedagoginen Aikakauskirja, 14, 119-136.

Leino, M., Hintsanen, M., Hintsa, T., Merjonen, P., \& Keltikangas-Järvinen, L. (2013). Family Factors and NEET Status: An Estonian Case Study. Research in Post-Compulsory Education, 18, 115-126. http://dx.doi.org/10.1080/13596748.2013.755845

Leino, M., \& Lahelma, E. (2002). Constructing and Educating 'Problem Children’: The Case of Post-Socialist Estonia. International Journal of Inclusive Education, 6, 79-90. http://dx.doi.org/10.1080/13603110110091634

Liimets, H. (1998). Kuidas Õppeprotsess Kasvatab? (How Does the Learning-Process Educate?). Tallinn: TPÜ Kirjastus.

Martin, R. P. (1989). Activity Level, Distractibility, and Persistence: Critical Characteristics in Early Schooling. In G. A. Kohnstamm, J. E. Bates, \& M. K. Rothbart (Eds.), Temperament in Childhood (pp. 451-462). Chichester: John Wiley \& Sons, Ltd.

Mullola, S. (2012). Teachability and School Achievement: Is Student Temperament Associated with School Grades? Research Report/University of Helsinki, Faculty of Behavioural Sciences, Department of Teacher Education. Helsingin Yliopisto: Research Report 341.http://urn.fi/URN:ISBN:978-952-10-7866-8

Mullola, S., Hintsanen, M., Jokela, M., Lipsanen, J., Alatupa, S., Ravaja, N., \& Keltikangas-Järvinen, L. (2014). Associations between Teacher-Rated versus Self-Rated Student Temperament and School Achievement. Scandinavian Journal of Educational Research, 58, 147-172. http://dx.doi.org/10.1080/00313831.2012.725094

Mullola, S., Jokela, M., Ravaja, N., Lipsanen, J., Hintsanen, M., Alatupa, S., \& Keltikangas-Järvinen, L. (2011). Associations of Student Temperament and Educational Competence with Academic Achievement: The Role of Teacher Age and Teacher and Student Gender. Teaching and Teacher Education, 27, 942-951. http://dx.doi.org/10.1016/j.tate.2011.03.005

Mullola, S., Ravaja, N., Lipsanen, J., Alatupa, S., Hintsanen, M., Jokela, M., \& Keltikangas-Järvinen, L. (2012). Gender Differences in Teachers' Perceptions of Students' Temperament, Educational Competence, and Teachability. British Journal of Educational Psychology, 82, 185-206.

Mullola, S., Ravaja, N., Lipsanen, J., Hirstiö-Snellman, P., Alatupa, S., \& Keltikangas-Järvinen, L. (2010). Teacher-Perceived Temperament and Educational Competence as Predictors of School Grades. Learning and Individual Differences, 20, 209-214. http://dx.doi.org/10.1016/j.lindif.2010.01.008

Nygard, T. (1998). Erilaisten historiaa (The History of Deviant People). Jyväskylä: Atena. 
Nyqvist, L. (1997). Sosiaalipedagogiikka ja Sosiaalityö. Suomalaista Sosiaalipedagogiikkaa Kehittämässä. Raportti Valtakunnallisilta Sosiaalipedagogisilta Päiviltä Porissa (14.-15.11.1997), 30-36.

Pinker, S. (1999). Words and Rules. Science Masters. Bungay: Clays Ltd.

Rothbart, M. K., \& Jones, L. B. (1998). Temperament, Self-Regulation, and Education. School Psychology Review, $27,479$.

Rudasill, K. M., \& Rimm-Kaufman, S. E. (2009). Teacher-Child Relationship Quality: The Roles of Child Temperament and Teacher-Child Interactions. Early Childhood Research Quarterly, 24, 107-120. http://dx.doi.org/10.1016/j.ecresq.2008.12.003

Silvennoinen, H. (1992). Huono-osaisuus ja Koulutus (Marginality and Schooling). Kasvatus, 3, 256-267.

Unt, I. (1996). The Aspect of Gifted Children in the Child-Centred Education. In I. Kraav (Ed.), Missugust Isiksust Me Kasvatame (What Kind of Person Do We Educate) (pp. 27-39). Tartu: Tartu Ülikool.

Veugelers, W. (2011a). Introduction: Linking Autonomy and Humanity. In W. Veugelers (Ed.), Education and Humanism Linking Autonomy and Humanity (pp. 1-8). https://www.sensepublishers.com/media/299-education-and-humanism.pdf

Veugelers, W. (2011b). A Humanist Perspective on Moral Development and Citizenship Education. Empowering Autonomy, Humanity and Democracy. In W. Veugelers (Ed.), Education and Humanism Linking Autonomy and Humanity (pp. 9-34). https://www.sensepublishers.com/media/299-education-and-humanism.pdf

Washington, D. C. (1998). National Board for Professional Teaching Standards. http://www.intime.uni.edu/model/teacher/teac4.html 